\title{
RESULTS OF LEARNING SCIENCE CLASS 3 WITH DISCUSSION METHOD HELPED MEDIA GREAT IMAGES
}

\author{
Izzaturrahmah $^{1}$, Ahmad Harjono ${ }^{2}$, Moh. Irawan Zain ${ }^{3}$ \\ 1,3 Elementary Education Study Program, Universitas Mataram, Indonesia \\ ${ }^{2}$ Physics Education Study Program, Universitas Mataram, Indonesia
}

\section{Article Info}

Article history:

Received: $10-12-2020$

Revised: 28-12-2020

Published: 31-01-2022

Keywords:

Learning

Science

Elementary Education

\begin{abstract}
This research is aim to know the effect of discussion method by using serial image media toward study result of science class III cluster III subdistrict of Sekarbela lesson year 2019/2020. This research using Quasi Experiental Design type Nonequivalent Control Group Design. The sample ethnic that used is Purposive Sampling, one of the researcher opinion of using this sample type because the average of study result of science students are same, that was taken from placement test. Total of this sample are 58 students. Students result data tested is normalization using Kolmogorov-Smirnov formula said that it has normal distribution then later tested homogenity using Levene statistic formula said it has varian homogen by using SPSS 21 for windows, at the end the tested shows that the data has normal distribution and tested homogen. Then tested hypothesis using independent sample t-test formula got t-value 1,013 as bis as and t-table as big as 3,172 with standart of significant are 5\%. The explanation above show that t-value $>\mathrm{t}$-table so it can conclude that Ha accepted and HOrejected. This case shows that there is effect of discussion method by using serial image media toward study result of science class III cluster III subdistrict of Sekarbela lesson year 2019/2020.
\end{abstract}

This is an open access article under the CC BY-SA license.

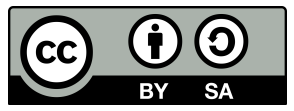

\section{Corresponding Author:}

Izzaturrahmah,

Elemetary Education Study Program, Universitas Mataram

Jl. Majapahit No. 62, Mataram, Indonesia

Email: izaarahma97@gmail.com

\section{INTRODUCTION}

Natural Sciences is the science of natural phenomena that are outlined in the form of facts, concepts, principles and laws that are proven to be true. Natural Sciences also provides an understanding of how we can live by adapting to these things. Good learning is certainly learning that makes students understand what material has been explained by the teacher, and when learning takes place the condition of the class becomes active and fun. Of course, this cannot be separated from the role of the teacher in managing the teaching and learning process, acting as a facilitator who seeks to facilitate the needs of students (Tyaningsih, Baidowi, \& Maulyda, 2020).

The teacher conveys more material in lectures and is interspersed with questions and answers, then students are silent listening to the material presented by the teacher while taking notes even though there are a small number who do not take notes. Students take notes exactly as the teacher wrote on the blackboard. At 
the time of the learning process there were some students who seemed less concentrated at the time of learning (Affandi, Saputra, \& Husniati, 2020). Many learning models can be applied to students, but researchers see that science is a scientific discipline that requires an active process in its implementation. One of the learning models that can be used is the discussion method assisted by serial image media (Erduran, Simon, \& Osborne, 2018).

Kariadinata et al. (2018), states that discussion is one of the learning methods so that students can share their knowledge, views, and skills. The purpose of the discussion method is to explore the opinions of students and their views that allow students to express their different opinions and make problem solving views of these views together. This discussion method can be applied in various types of subjects ranging from social sciences and natural sciences. The advantages of using the discussion method are that it is simple and tends to be fun, it can be used as a means as well as a vehicle to practice speaking skills among group members, can grow students' self-confidence, and train students' critical and analytical skills (Megawanti, 2012).

Learning media is one of the determining factors for success in learning. Through the media, the learning process can take place in a more interesting and fun way. Sidiq et al. (2020), states that serial pictures are a series of activities or stories that are presented sequentially. With serial pictures, students are trained to express the scenes and activities in the pictures. Research on the discussion method and serial image media has been carried out by several previous researchers. From the results of research that has been carried out, it can be concluded that using the discussion method can improve student learning outcomes.

\section{RESEARCH METHOD}

The type of research used is quasi-experimental. This research was conducted at SDN 2 and SDN 4 Kuranji in Semester I of the 2019/2020 Academic Year. The variables used in this study are independent and dependent variables. The independent variable in this study is the discussion method assisted by serial pictures, while the dependent variable is learning outcomes. The population used is all class III students in Cluster III, Sekarbela District, while the population used is class III SDN 2 Kuranji and SDN 4 Kuranji. Researchers choose samples using certain considerations, one of the techniques used is purposive sampling. One of the researchers' considerations is that the average value of student learning outcomes is the same, which was previously obtained through a placement test. This equality is known through the homogeneity test using the costat application, based on the results of the homogeneity test, it is found that the equivalent schools are class III at SDN 2 and 4 Kuranji, totaling 58 people. Then the two classes were randomly selected to determine the experimental class and the control class. The experimental class in this study was SDN 2 Kuranji while SDN 4 Kuranji was chosen to be the control class. The data collection technique used is by carrying out observations and tests. The data collection instrument used in this study used an observation sheet and a test sheet. The observation sheet is used to measure the activities of teachers and students during the learning process (Jennings, 2018). The teacher's activity sheet was analyzed by giving a score of "1" on the learning steps that were carried out and giving a score of "0" on the learning steps that were not implemented. The test sheet used in this study was a multiple-choice test with 15 questions.

Learning outcomes data were obtained through pre-test and post-test in the experimental class and control class. The data analysis technique used normality test using the Kolmogorov Smirnov formula, as well as using the homogeneity test using the Levene statistic formula, and hypothesis testing using the independent sample t-test formula assisted by the SPSS version 21.0 application by windows (Tout, 2020). Then there is a follow-up test that aims to test how much influence the discussion method assisted by serial picture media has on science learning outcomes by using the calculation of the effect size test.

\section{RESULT AND DISCUSSION}

\subsection{Result}

\subsubsection{Results of Observation of Learning Implementation}

The results of the percentage implementation of the discussion method syntax assisted by serial image media in the experimental class can be seen in Table 1 as follows: 
Table 1. Percentage of Teacher Activities Implementation

\begin{tabular}{ccc}
\hline Meeting & Percentage (\%) & Criteria \\
\hline 1 & 83.33 & Good \\
2 & 93.33 & Very Good \\
3 & 100 & Very Good \\
\hline
\end{tabular}

Then the results of observing student activities during learning, here are the results of the average observation of student activities in three meetings:

Table 2. Percentage of Student Activities Implementation

\begin{tabular}{ccc}
\hline Meeting & Percentage $(\%)$ & Criteria \\
\hline 1 & 80.45 & Good \\
2 & 83.66 & Very Good \\
3 & 100 & Very Good \\
\hline
\end{tabular}

Based on the results of the percentage of implementation of learning in the experimental class, it can be seen that the value of the implementation of learning carried out by researchers is very good.

\subsubsection{Data Homogeneity Test Results}

Homogeneity test was used to determine whether the experimental class and control class in this study had homogeneous variants or not. The homogeneity test was carried out by using the analysis of variance (f test) using the SPSS version 21 by windows application. Based on the results of the homogeneity test carried out using Levene statistics, the post-test significance level of students' science learning outcomes was $0.753>$ 0.05 , it can be concluded that the data of the two classes had homogeneous variants.

\subsubsection{Hypothesis Test Results}

Hypothesis testing was carried out after the data normality test and homogeneity test. Hypothesis testing was carried out after the two requirements were met, namely that the two classes were normally distributed and homogeneous. The hypothesis test in this study used an independent sample t-test which was calculated using the SPSS 21.0 by windows application assistance with a significance level of $5 \%$ or 0.005 .

Based on the results of the hypothesis testing that has been carried out, it can be obtained that t-value is 3,172 with degrees of freedom $\mathrm{df}=\mathrm{n}-2$ or $56-2=54$ at a significance level of 0.002 . $; 1.6730 .552$, it can be concluded that there is an effect of the discussion method assisted by serial pictures on the learning outcomes of class III science in Cluster III, Sekarbela District so that the alternative hypothesis (Ha) is accepted and the null hypothesis $(\mathrm{H} 0)$ is rejected.

\subsection{Discussion}

The discussion method is used as a means for students to be actively involved in the learning process. Mayombe \& Lombard (2016), states that discussion is one of the learning methods so that students can share their knowledge, views, and skills. This research is supported in line with the research that has been carried out by Sari, et al which stated that applying the discussion method using image media can increase student learning activities and outcomes. The increase in student learning outcomes can be seen from each cycle that has increased (Al Ani \& Al Attar, 2017). This can be seen from the implementation of the first cycle in the application of the discussion method using image media an increase in student activity from $51 \%$ to $73.2 \%$ while in the second cycle there was an increase of $10.4 \%$ from $73.2 \%$ to $83.6 \%$ which includes in very active criteria. As is the case in this study, when treatment was given using the discussion method, the teacher guided students during the discussion and guided students to stay focused in solving a discussion problem, then find out the answer by carrying out discussions with their peers or groups, so that students can express their respective opinions that make the implementation of learning active. This research is also strengthened by Gayatri et al, namely by using the discussion method can improve students' science learning outcomes. Through the discussion method, it will arouse students' learning enthusiasm and the learning process will be more effective because students can express their own opinions, students will also feel more comfortable if carrying out discussions with peers. So, by using the discussion method assisted by serial picture media, it will feel more active, creative, fun and not boring so that by using this discussion method, student learning outcomes can increase (de Aguilera \& Mendiz, 2003). 
In addition to using the discussion method, the researcher also carried out learning in the experimental class with the help of image media, the image media used in this study was serial image media. Moore (2009), states that serial pictures are a series of activities or stories that are presented sequentially. With serial pictures, students are trained to express the scenes and activities in the pictures. In line with previous research, Khalim has conducted research, namely learning outcomes in learning using image or photo media and discussion methods have increased from cycle I to cycle II. The increase in learning outcomes occurs because students get a lot of information from the use of image or photo media in addition to learning resources from books and explanations from the teacher, so that students have a strong basic knowledge. In addition, a factor that can support the improvement of learning outcomes is the discussion method which has the advantage of being able to express opinions between students with one another (Sumardi, 2019). Then Elpis has carried out a similar study, namely by using image media to improve student learning outcomes. At the time of learning, it was seen that students were very interested in the use of image media, so that students paid attention and took lessons seriously. This is also in line with the research that has been carried out by Khafidhotun, before being given treatment the students looked less active in the implementation of learning, bored quickly, not enthusiastic and lacked interest in learning when learning took place. After applying the discussion method assisted by serial picture media, students looked enthusiastic in learning, because the discussion involved students directly in the learning process so that it attracted the attention of students (Beler-Baykal, 2010). The use of image media can also attract the attention and curiosity of students.

Based on the analysis of the science learning outcomes of students from the experimental and control classes, it can be seen that science learning using the discussion method assisted by serial pictures shows different learning outcomes compared to science learning using lecture and question and answer methods (Education, 2011). This can be seen based on the acquisition of the pre-test, post-test scores, as well as the increase in the average score from pre-test to post-test. The difference seen in the pre-test scores, is that the average value of the experimental class students is higher than the control class. Then, after being given different treatments, both classes were given a post-test. The post-test results showed that the average score of the experimental class was higher than the control class (Kaya \& Deniz, 2020).

Based on this, it can be concluded that the use of the discussion method assisted by serial picture media as a learning aid that can foster interest and motivation of students in learning, students are not only listeners but also can play an active role in the learning process. Therefore, the discussion method and serial image media when applied in learning can improve learning outcomes that are higher or better than the previous value. So, the use of the discussion method assisted by serial picture media can be said to be effective as an alternative for teachers in the implementation of learning. Based on the research that has been obtained, there is an effect of the discussion method assisted by serial picture media on the science learning outcomes of class III students at SDN Gugus III, Sekarbela District.

\section{CONCLUSION}

Based on data analysis on the results and discussion of research about the Discussion Method assisted by Serial Picture Media on Natural Science Learning Outcomes CLASS III SDN Gugus III Sekarbela District for the 2019/2020 Academic Year, the researcher can conclude that there is a positive and significant effect between the Discussion Method assisted by Serial Picture Media Against CLASS III Science Learning Outcomes at SDN Cluster III, Sekarbela District, 2019/2020 Academic Year. This is indicated by the results of data analysis using the product moment formula with the help of the SPSS application t-value $>\mathrm{t}$-table 1,701. Then the proposed $\mathrm{H} 0$ is rejected and on the contrary $\mathrm{Ha}$ is accepted, at a significance level of 5\% so that it can be declared "significant".

\section{REFERENCES}

Affandi, L. H., Saputra, H. H., \& Husniati. (2020). APAKAH TINGKAT KEBAHAGIAAN BISA MENJELASKAN HASIL BELAJAR SISWA SEKOLAH DASAR? PROGRES PENDIDIKAN, 1(3), 168-176.

Al Ani, M. A., \& Al Attar, A. T. (2017). The Role of Private School Principals in Total Quality Mangagement and its Relation with Educational Leadership Style. Journal of Educational and Psychological Studies [JEPS], 11(3), 687. doi:10.24200/jeps.vol11iss3pp687-706

Beler-Baykal, B. (2010). The Sage handbook of philosophy of education. Choice Reviews Online, 32(4), 89109. doi:10.5860/choice.48-2217 
de Aguilera, M., \& Mendiz, A. (2003). Video games and education: (Education in the Face of a "Parallel School"). Computers in Entertainment (CIE), 1(1), 1-10. doi:10.1145/950566.950583

Education, H. (2011). Higher Education: Students at the Heart of the System.

Erduran, S., Simon, S., \& Osborne, J. (2018). Tapping into argumentation: Developments in the application of Toulmin's Argument Pattern for studying science discourse. Science Education, 88(6), 915-933. doi:10. $1002 /$ sce. 20012

Kariadinata, R., Sugilar, H., Farlina, E., \& Kurahman, O. T. (2018). The Sociomathematical Norms in Linear Algebra Lecture. In Icse 2017 - 2nd international conference on sociology education sociomatematic (Vol. 2, pp. 715-720). doi:10.5220/0007104707150720

Kaya, I., \& Deniz, M. E. (2020). The effects of life skills education program on problem behaviors and social skills of 4-year-old preschoolers. Elementary Education Online, 19(2), 612-623. doi:10.17051/ilkonline. 2020.692983

Mayombe, C., \& Lombard, A. (2016). The importance of material resources and qualified trainers in adult nonformal education and training, centres in South Africa. International Research Education, 6(2), 187-204. doi:10.1007/s11159-016-9548-7

Megawanti, P. (2012). Permasalahan Pendidikan Dasar Di Indonesia. Jurnal Ilmiah Pendidikan MIPA, 12(3), 113-124. doi:10.30998/formatif.v2i3.105

Moore, T. W. (2009). Philosophy of education: An introduction. doi:10.4324/9780203861103

Sidiq, D. A. N., Fakhriyah, F., \& Masfuah, S. (2020). Partisipasi Guru Pelaksanaan Bimbingan dan Konseling di SD Kota Mataram NTB. Progres Pendidikan, 1(2), 99-105.

Sumardi, K. (2019). Adult Education through Multiple Method For Poor Rural Illiterate Women in Indonesia. Journal of Education and Learning (EduLearn), 6(4), 243. doi:10.11591/edulearn.v6i4.169

Tout, D. (2020). Evolution of adult numeracy from quantitative literacy to numeracy: Lessons learned from international assessments. International Review of Education, 23(3), 456-478. doi:10.1007/s11159-02009831-4

Tyaningsih, R. Y., Baidowi, \& Maulyda, M. A. (2020). Integration of Character Education in Basic Mathematics Learning in the Digital Age. Atlantis Press, 465(Access 2019), 156-160. 